\title{
Heidegger's Crisis: Philosophy and Politics in Nazi Germany (Cambridge: Harvard University Press, 1993) by Hans Sluga.
}

\section{Reviewed by Lee Kerckhove Loyola University Chicago}

The current debate over Heidegger's Nazism began with the appearance of Victor Fariás' Heidegger et le nazisme in 1987.1 Despite occasional polemical excesses, Fariás succeeded in revealing the depth of Heidegger's commitment to National Socialism and the disingenuousness of his later attempt to account for his actions after his resignation from the rectorship of the University of Freiburg in 1934.2 Heidegger's active support of the National Socialist regime was not, as he later claimed, restricted to the period of his term as rector. After his resignation from the rectorship, Heidegger continued his collaboration with the regime by secretly denouncing colleagues and students. ${ }^{3}$ He remained a dues paying member of the Nazi party until the end of the war and in 1953 published a modilied version of a lecture originally delivered in 1933 entitled An Introduction to Metaphysics which retained the notorious remark about the "inner truth and greatness" of the Nazi movement. 4

Despite more even-handed treatments of the issue of Heidegger's Nazism 5 , Fariás polemics set the tone for the partisan debate that ensucd. Critics of Heidegger seized the opportunity to dismiss his philosophy because of its purpotedly intrinsic link to Nazism.6 Supporters of

IVictor Fariás, Heidegger et le nazisme, trans. Myriam Benarroch and Jean-Baptiste Grasset (Lagrasse, France: Editions Verdier, 1987). This work appears in English as Heidegger and Nazism, trans. Paul Burrell with Dominic DiBernardi (Philadelphia: Temple University Press, 1989).

2Cf. "'Only a God Can Save Us': Der Spiegel's Interview with Martin Heidegger (1966)," in The Heidegger Controversy: A Critical Reader, ed. Richard Wolin (Cambridge: The MIT Press, 1993), 101: "After I stepped down as rector I limited myself to teaching. In the summer semester of 1934 I lectured on 'Logic.' In the following semester I gave the first Hölderlin lecture. In 1936, I began the Nietzsche lectures. Anyone with ears to hear heard in these lectures a confrontation with National Socialism."

3Fariás, Heidegger and Nazism, 209-212.

4Martin Heidegger, An Introduction to Metaphysics, trans. Ralph Manheim (New Haven: Yale University, 1987), 199.

5See, e.g., Hugo Ott, Martin Heidegger: Unterwegs zu seiner Biographie (Frankfurt/New York: Campus Verlag, 1988). Sce also, Thomas Shechan, "Heidegger and the Nazis," New York Review of Books 35, no. 10 (June 16, 1988), 38-47.

6Heidegger himself confirmed such a connection in a conversation with Karl Löwith in 1936. See Löwith, "My Last Meeting with Heidegger in Rome, 1936," in Wolin. The Heidegger Controversy, 142. After remarking that he believed that Heidegger's commitment to Nazism was essentially connected to his philosophy, Löwitch notes 
Heidegger generally sought to separate Heidegger the Nazi from Heidegger the philosopher. Whatever Heidegger's degree of involvement with the Nazis, they maintained, it is not relevant to Heidegger's project of rethinking the meaning of Being. 7

Unfortunately, the combatants' narrow focus on the minutiae of Heidegger's political debacle obscured a number of crucial issues. The debate neglected to consider whether Heidegger's Nazism represented not merely the moral and intellectual failure of a particular individual, but perhaps also the failure of an entire generation of German philosophers. By focusing on Heidegger to the exclusion of all else, the substantive historical issue of the roles played by other philosophers within the Third Reich was overlooked. Perhaps more importantly, the deeper philosophical issues concerning the relationship of philosophy and politics that are raised by the complicity of German philosophers with the Third Reich were left untouched.

Hans Sluga's Heidegger's Crisis: Philosophy and Politics in Nazi Germany represents a thoughtful and determined effort to rise above the partisan debate and address the broader philosophical and historical issues raised by Heidegger's Naxism. Sluga situates Heidegger's Nazism within the context of 19 th and 20 th century German intellectual history. His thesis is that Heidegger's political crisis in 1933 was not simply the crisis of a particular philosopher, but rather the crisis of an age. 8 If true, Sluga's thesis has numerous implications for our understanding of Heidegger's Nazism. First, if Heidegger's personal political crisis were a reflection of a more widespread spiritual crisis within Germany, then the issue of Heidegger's personal responsibility would have to be re-examined. Second, Sluga's thesis would effectively undermine any attempt to draw a direct link between Heidegger's philosophy and Nazism by showing that many other philosophers, including some who were philosophically at odds with Heidegger, also aligned themselves with the Nazi movement. Finally, Sluga's thesis would also imply that most indictments (and most defenses) of Heidegger are misguided. By ignoring the larger historical context of Heidegger's crisis they exaggerate Heidegger's role and overlook issues of greater philosophical signilicance. 9

that Heidegger "agreed with me without reservation, and added that his concept of 'historicity' was the basis of his political 'engagement.' He also left no doubt concerning his belicf in Hitler."

7Thomas Sheehan, "A Normal Nazi," New York Review of Books (January 14, 1993), 30: "Strategies for coping with this new and damning information ranged from partial disclaimers . . . to exculpatory incantations . . . to triage: 'Admit the Nazism, but save the philosophy!"'

HHans Sluga, Heidegger's Crisis: Philosophy and Politics in Nazi Germany, (Cambridge: Harvard Universily Press, 1993), 246.

9Jbid., 154-5: "Against the background of history effaced, the significance of Heidegger's actions and words looms larger than it actually was. Uninformed 
Central to Sluga's argument is his reconstruction of the philosophical context of Heidegger's crisis in 1933. The date is significant because it marks not only the beginning of Hitler's chancellorship, but also the beginning of Heidegger's rectorship. Sluga adopts a Foucauldian interpretive strategy to demonstrate the continuity between these two events. German philosophy and politics in 1933 share a common discursive framework, he argues, that forms the historical a priori of the age. 10 On Sluga's view, the discursive framework of Germany in 1933 was composed of four ideas: crisis, nation, leadership, and order. Collectively, these ideas comprised the basis of the "symbolic environment" that determined both philosophical thinking in Germany in the years leading up to 1933, as well as the political engagement of philosophers. 11 Consequently, the decision to become politically active on the part of so many German philosophers in 1933 "was not simply the result of individual decisions," but was also the result of the presuppositions implicit in their intellectual environment.12

Although the Nazi's manipulated and exploited the symbolic environment, they did not create it. Sluga traces the themes of crisis, nation, leadership, and order to their origins in the writings of Fichte und Nietzsche. Fichte's appeal to the Nazis lay in his nationally oriented socialism, his recognition of the present moment as historically decisive, and his political involvement in the name of philosophy. Writing during the turmoil of the Franco-Prussian War, Fichte's Speeches to the German Nation indicate a crisis of German national identity. The crisis of identity demanded a renewal of the German nation through leadership that was capable of understanding the true political order. 13 According to Sluga, Fichte became

hindsight makes Heidegger a singular figure and suggests a direct link between his thought and Nazi ideology."

10Sluga's Foucauldian interpretive strategy is designed to avoid reductionistic interpretations of Heidegger' Nazism. He wants to avoid a Marxist interpretation that would reduce the philosophical realm to an epiphenomenon of the political. An example of such an interpretation can be found in Monika Leska. Philosophen im 'Drilten Reich': Studie zu Hochschule-und Philosophiebetrieb in fascistishcen Duetschland (Berlin: Dietz Verlag, 1990). Leska maintains that beneath the apparent differences among the various philosophical schools in Germany in 1933 was a common imperialistic, bourgeois foundation that was consonant with fascist ideology. Conversely, Sluga also wants to avoid interpretations that reduce the political field to the philosophical field, e.g., Pierre Bourdicu, The Political Ontology of Martin Heidegger (Stanford: Stanford University Press, 1991). For his discussion of these interpretive issues see Sluga, 246-248.

1IIbid., 67: "It determined their philosophical thinking as well as their political involvement."

12 Ibid.

13ibid., 40: "Fichte's Addresses, in sum, rested squarely on the belief that a point of crisis had been reached in German history--a crisis that was at once political and philosophical, a crisis that concerned in particular the German people and the 
the rallying point for conservative philosophers between the First and the Second World Wars who saw him as the spiritual ancestor of their own nationalistic concerns.

In opposition to these reform-minded conservatives was a group that Sluga refers to as the "philosophical radicals." This group of philosophical radicals, which included Heidegger, identified more closely with Nietzsche than with Fichte and German idealism. Nietzsche's appeal resided primarily in his purported social Darwinism, in his affirmation of the body, struggle, strong leadership, and in his critiques of liberalism and Christianity. Nietzsche radicalized the idea of crisis, transformed it from a German to a European phenomenon, and called for the revaluation of all values in the face of nihilism and the death of God. 14

The idea of crisis is the first component in Sluga's reconstruction of the historical a priori of 1933. The modern German sense of crisis originated with the loss of World War I and increased with the instability of the Weimar Republic. Spengler's Decline of the West crystallized the sense of crisis and provides Germans of all cultural levels with the language of crisis. In politics and philosophy the idea of crisis was linked to the idea of revolution. Nazism never abandoned its self-consciously revolutionary character and never relinquished the idea of crisis "as a basic element of its ideology." 15 Thus the appeal of Nazi ideology to so many philosophers who had incorporated the concept of crisis into their own philosophizing via the nation of intellectual revolution.

Sluga argues that the framework of crisis is problematic because it creates an environment in which 100 much emphasis is placed on decision and action. Sluga sees the notion of great crisis as a destructive habit of modern thought; historical developments cannot be adequately understood on the model of radical discontinuity of the present and the past. Historical crises, when they do occur, are not sudden transformations brought about by heroic acts of will. More often they are the results of the accumulation of incremental and almost imperceptible actions and decisions. Therefore, Sluga concludes, one lesson we can draw from the political actions of philosophers in the Third Reich is that we must abandon the political discourse of crisis:

What is needed is that those in politics think not in terms of revolution and crisis, grand decisions and sudden transformations, but in terms of patient explorations and continuous partial shifts. 16

understanding they had of themselves, a crisis of leadership calling for the reestablishment of a true order."

14Ibid., 42-49.

1.5!bid., 56.

16lbid., 74. 
Sluga comes to equally negative conclusions about the other elements of the historical a priori operative in Germany in 1933, i.e., the ideas of nation, leadership, and order. The myth of German exceptionalism, and what Sluga calls the "German Mission," occupied the attention of both philosophers and politicians. Central to the myth of German exceptionalism were beliefs about the primordiality of the German language, the geographical and intellectual centrality of Germany, and the political, moral, and intellectual purity of the German race. Thus when Hedeigger spoke in his rectorial address about the unique spiritual mission of the German people, Sluga argues that he is not initiating a new discourse, "but inserting himself into one that already had a long history." 17 The discursive framework of German exceptionalism and centrality bridge Heidegger's philosophy and the politics of the time. The effect of this discourse, however, was not an overcoming of class and race divisions but rather the creation of "a sharp boundary between a privileged and an underprivileged group." 18 In other words, it served to create a "binary logic" of exclusion. 19 While we can question the justification given for claims of German exceptionalism, its effects are unmistakable:

Once adopted, the discourse of identity, of folkdom, of a distinctive folkish mission, of the historical meaning and uniqueness of the nation, indeed seems inescapable, more so than any empirical fact could be, but it is our discoursc that constitutes these objects and makes them inescapable. Once the idea grips us, a picture takes hold that we cannot evade--it is grounded in our discourse and that discourse repeats it to us inexorably. 20

Belief in the centrality of the German nation is a crucial aspect of Heidegger's political involvement. The idea of leadership also plays a crucial role. Sluga argues that it was Heidegger's inability to free himself from the Platonic tradition, in which the well-ordered state requires philosophical leadership, that formed the core of his political involvement. Heidegger, in this respect no different from philosophers such as Fred Bäumler and Ernst Krieck, saw himself as the Third Reich's spiritual leader.

17lbid., 120. Cf. Heidegger's Rectorial Address, "The Self-Assertion of the German University," in Wolin, The Heidegger Controversy, 29: "The teachers and students who constitute the rector's following will awaken and gain strength only through being truly and collectively rooted in the essense of the German university. This essence will attain clarity, rank, and power, however, only when the leaders are, first and foremost and at all times, themselves led by the inexorability of that spiritual mission which impresses onto the fate of the German Volk the stamp of history."

18Ibid., 102.

19 lbid., 123.

20Ibid., 121. 
One implication of this line of argument is that Heidegger no longer appears unique in his ambition to become the philosopher of the Third Reich:

Heidegger's political engagement thus appears as an attempt to secure his philosophical influence in the unstable conditions of the 1930's. His rectorial address was more than an expression of support for the Nazis; it was also meant to promote Heidegger's own philosophy and his own claims to spiritual leadership. 21

Viewed in this light, Heidegger becomes simply another philosophical opportunist whose political engagement was determined, in part, by the discursive framework of leadership, and in part by self-interest.

Sluga concludes by drawing some lessons from the political experience of German philosophers for contemporary philosophy. We must come to recognize the interdependence of philosophy and politics. Philosophy is not independent of politics. It exists in a political field that serves to determine its discourse. On the other hand, philosophy also influences the political realm in which ideas and words, and questions of truth and falsity are extremely important. Because of the constantly changing form of this interdependence, Sluga reaches the somewhat skeptical conclusion that there can be no single, decisive meta-narrative that can conclusively describe the relationship between philosophy and politics. The relationship is inherently historical "and understandable only in its narrative uniqueness." 22

As a result, Sluga rejects the efforts of Nietzsche and Foucault to articulate a theory of philosophical/political interaction in terms of a general theory of truth and power. On Sluga's view, Nietzsche's metaphysics of the will to power lacks "authoritative arguments," while Foucault's theory of power is problematic because "[power] becomes, in his hands, a peculiar hluid draining invisibly through the capillaries of human socicly."23 Sluga rejects these attempts to articulate a metaphysics of power:

What we call power is, in fact, and ensemble of diverse relations of dependence and interdependence that include natural relations of cause and effect as well as social and political relations, relations of spatial and temporal order as well as institutional, logical, and symbolic relations of dependence. 24

21 Ibid., 173.

22lbid., 253.

2.3 lbid., 253.

24lbid., 254. 
Thus no meta-narrative of power is satisfactory as an explanation of the relationship of philosophy and politics: "the historical facts must speak for themselves." 25

There is something of a sclf-defeating nature in Sluga's effort to relativize Heidegger's Nazi involvement. By historicizing Heidegger's Nazism, we learn little of Heidegger's specific motivations for joining the Nazi party. In particular, we learn little of what Heidegger himself saw as "the inner truth and greatness" of the Nazi movement, i.e., "the encounter between global technology and modern man." 26 Moreover, Heidegger simply disappears in the course of the narrative. There is no substantial discussion of Heidegger until page 135, by which time one is left wondering if he is going to appear at all. Of course, this is the intentional result of Sluga's effort to de-emphasize the uniqueness of Heidegger's political engagement. But it is surely a problem when the nominal subject of the investigation is subsumed to methodological demands.

Another problematic feature of Sluga's work is his ambivalent adoption of a Foucauldian hermencutic of suspicion. The experience of Germany's philosophers counsels us to avoid grand, meta-narrative accounts of the relationship between philosophy and politics. We are cautioned not to get caught up in the discursive frameworks that may be operative at a given moment and "let the historical facts speak for themselves." But if it is the case, as Sluga maintains throughout this work, that discursive frameworks determine the realm of thought, then the facts are preciscly that which cannot speak for themselves. There are no facts outside of discursive frameworks that determine what will count as a fact. In appealing to the facts, Sluga's argument threatens to slide into an uncritical empiricism. As a result, he leaves us without any substantive guidelines for recognizing discourses that are dangerous and for removing them from the philosophical/political field.

Sluga overlooks the fact that meta-narratives of power such as those found in the writings of Nietzsche and Foucault are useful not only for their descriptive aspects, but also because they serve a diagnostic role. They allow us to recognize that formations of power are constitutive of discursive frameworks. But, more importantly, they allow us to change the discursive framework on the basis of this recognition. For example, in Ont the Genealogy of Morals Nietzsche describes the will to power not as a

25lbid., 255.

${ }^{26}$ An Introduction 10 Metaphysics. 199. For a thorough discussion of this facet of Heidegger's Nazism see Michacl E. Zimmerman, Heidegger's Confrontation with Modernity: Technology, Politics, Art (Bloomington: Indiana University Press, 1990). 
metaphysical principle but as a "major point of historical method."27 The point of this historical method is clearly diagnostic:

... all concepts in which an entire process is semiotically concentrated elude definition; only that which has no history is definable. At an earlier stage, on the contrary, this synthesis of 'meanings' can still be disentangled, as well as changed; one can still perceive how in each individual case the elements of the synthesis undergo a shift in value and rearrange themselves accordingly, so that now this, now that elements comes to the fore and dominates at the expense of others; and under certain circumstances one element ... appears to overcome all the remaining elements. 28

In other words, a meta-narrative of power can be precisely the right tool to escape from a given historical a priori.

Sluga's historicized account of the question of Heidegger's political debacle in 1933 is an extremely valuable contribution not only to the current debate over Heidegger's Nazism, but also to the question of philosophy's relation to politics. Sluga effectively dismantles the myth of Heidegger's political uniqueness by contextualizing his political involvement. Sluga's conclusion is therefore useful for attenuating the factional spirit of the contemporary debatc. Heidegger's political shortsightedness can now be seen for what it was--the moral and intellectual failure of a large segment of an entire generation of German philosophers. Those who would see this as a victory for Heidegger are, however, cautioned that it is a pyrrhic victory at best.

27Friedrich Nietzsche, On the Genealogy of Morals, in Basic Writings of Nietzsche, trans. Walter Kautmann and R. J. Hollingdale (New York: The Modern Library, 1968), second essay, no. 12, 514 .

28lbid., no. 13, 516 . 